\title{
The Bioinorganic Periodic Table
}

\author{
Eva Freisinger ${ }^{*}$ and Roland K. O. Sigel ${ }^{*}$
}

\begin{abstract}
Life depends on metals. While carbon, in terms of abundance and versatility, is considered THE element of life, the vast variety and diversity of the chemistry taking place in living organisms could not be achieved without metal ions. More than twenty metals are found in the human body, most of them being essential, some beneficial, and for others it is still unknown what role they might fulfil in a living cell. Here we give a short introduction into the bioinorganic world of the periodic table, providing just a few examples of key metals for life and aiming to give a flavour to gain further insights into this exciting field of inorganic chemistry at the intersection to the life sciences.
\end{abstract}

Keywords: Bioinorganic chemistry $\cdot$ Metal ions $\cdot$ Metalloenzymes $\cdot$ Periodic Table $\cdot$ Trace metals

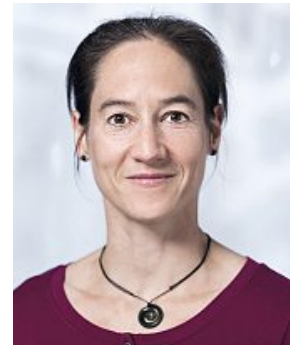

Eva Freisinger studied Chemistry at the University of Dortmund, Germany, where she also obtained her $\mathrm{PhD}$ in the group of Prof. Bernhard Lippert. After a postdoc at SUNY Stony Brook, USA, with Prof. Caroline Kisker, she moved to the University of Zurich, where she has performed independent research ever since. From 2008 to 2014 she held an SNF-Förderungsprofessur and received her habilitation in Bioinorganic Chemistry in 2014. In 2018 she became Associate Professor for Bioinorganic Chemistry and Chemical Biology. Her research is focused on the study of plant metallothioneins with an additional interest in the sequence-specific modification of nucleic acids. She serves on a number of advisory boards for international conference series, since 2014 she is the secretary of the EuroBIC conference series, is co-chair of ICBIC-19 in Interlaken, Switzerland, is an editorial board member of the Journal of Inorganic Biochemistry, and one of the editors of the Metal Ions in Life Sciences series from Volume 18 on.

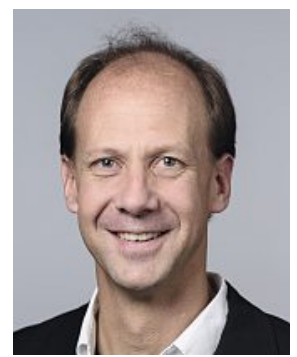

Roland K. O. Sigel studied Chemistry at the University of Basel, Switzerland, followed by a $\mathrm{PhD}$ at the University of Dortmund, Germany, and a postdoc at Columbia University, USA. He is currently a Full Professor of Chemistry at the University of Zurich, Switzerland, which he joined in 2003 as an Assistant Professor. In 2016 he became Dean of Studies and in 2017 Dean of the Faculty of Science of the University of Zurich. Roland Sigel has received numerous awards including a PhD Distinction, an SNF-Förderungsprofessur, the EuroBIC Medal, the Alfred Werner Prize of the Swiss Chemical Society, and an ERC Starting Grant. He is co-chair of ICBIC-19 in Interlaken, Switzerland, is the Swiss representative of the EuChemS Division of Chemistry for Life Sciences, and the elected Secretary of the Society of Biological Inorganic Chemistry, as well as the ICBIC conference series. His scientific interests centre around the manifold aspects of metal ion binding to large nucleic acids applying an interdisciplinary approach including (bio)chemical syntheses,

\footnotetext{
${ }^{*}$ Correspondence: Prof. Dr. E. Freisinger, Prof. Dr. R. K. O. Sigel

E-mail: freisinger@chem.uzh.ch, roland.sigel@chem.uzh.ch

Department of Chemistry, University of Zurich, Winterthurerstrasse 190,

$\mathrm{CH}-8057$ Zurich
}

single molecule fluorescence (smFRET), and NMR spectroscopy. Roland has published more than 100 peer-reviewed publications, has given about 100 lectures at international conferences and Universities, and is co-editing the new series Metal Ions in Life Sciences.

\section{The Periodic Table of Inorganic Elements for Life - an Introduction}

\subsection{The Abundance, Bioavailability, and Properties of the Elements/Metals in the Environment}

The by far most abundant elements in the universe are hydrogen and helium, which make up $99.9 \%$ of all atoms in the universe. Being very light, $\mathrm{H}$ and $\mathrm{He}$ are mostly found in gravitational large astronomical objects like stars or large gas planets. Hence, when moving to smaller systems, like earth, the composition of elements changes dramatically. The geosphere - that is the lithosphere or earth's crust down to approximately $50 \mathrm{~km}$ depth, the hydrosphere, the atmosphere, and the biosphere - is composed of mostly O (48.9\%), Si (26.3\%), Al (7.7\%), Fe (4.7\%), Ca (3.4\%), $\mathrm{Na}(2.7 \%), \mathrm{K}(2.4 \%), \mathrm{Mg}(2.0 \%), \mathrm{H}(0.74 \%)$, and $\mathrm{Ti}(0.42 \%)$ (please note that depending on the source, these numbers alter slightly without changing the relative order). ${ }^{[1]}$ These ten elements account for $99 \%$ of the total mass; in other words, the remaining 84 naturally occurring elements on earth add up to just $1 \%$.

One might think that the elements most abundant on earth are also those used primarily by life. There are, however, two main factors to consider: bioavailability and chemical properties. While the chemical property fit is the key factor for the theoretical applicability of an element for a desired process, the bioavailability of this element determines its actual use by the respective organism. Accordingly, the correlation between the geospheric abundance of elements and their relative distribution in, for example, the human body (Table 1) is low. A rather comprehensive series of reviews on biogeochemical cycles of elements, as well as the biogeochemistry, availability and transport of metals in the environment has been published elsewhere. ${ }^{[2,3]}$

How do we actually take up nutrients? Ingested food is the main source, followed by water, while inhalation would be the last possibility, certainly with the least importance. Going down the food chain there is food from animal or plant sources. While nutrient uptake by animals is not so different from human uptake, it comes mainly down to the bioavailability of elements, and in the scope of this article, to metal ions, their salts and complexes, for plants. A main factor for the bioavailability of metal ions is certainly their total concentration in the soil/water. So called 
Table 1. Approximate distribution of elements in a human adult of $70 \mathrm{~kg}$ weight (taken from ref. [1]).

\begin{tabular}{|l|c|l|l|l|r|l|r|r|r|}
\hline Element & $\mathbf{k g}$ & Element & $\mathbf{g}$ & Element & $\mathbf{m g}$ & Element & $\mathbf{m g}$ & Element & mg \\
\hline $\mathrm{O}$ & 45.8 & $\mathrm{~K}$ & 150 & $\mathrm{Rb}$ & 1120 & $\mathrm{Al}$ & 35 & $\mathrm{Mo}$ & 5 \\
\hline $\mathrm{C}$ & 12.7 & $\mathrm{Na}$ & 105 & $\mathrm{Sr}$ & 280 & $\mathrm{~Pb}$ & 35 & $\mathrm{Co}$ & $\sim 2$ \\
\hline $\mathrm{H}$ & 7.1 & $\mathrm{Cl}$ & 98 & $\mathrm{Cu}$ & 210 & $\mathrm{As}$ & 35 & $\mathrm{Cr}$ & $\sim 2$ \\
\hline $\mathrm{N}$ & 2.1 & $\mathrm{Mg}$ & 33 & $\mathrm{Br}$ & 140 & $\mathrm{Ba}$ & 21 & $\mathrm{Li}$ & $\sim 2$ \\
\hline $\mathrm{Ca}$ & 1.1 & $\mathrm{Fe}$ & 4.2 & $\mathrm{Sn}$ & 140 & $\mathrm{~V}$ & 21 & $\mathrm{Ni}$ & $\sim 1$ \\
\hline $\mathrm{P}$ & 0.7 & $\mathrm{Zn}$ & 2.8 & $\mathrm{I}$ & 70 & $\mathrm{~B}$ & 14 & & \\
\hline $\mathrm{S}$ & 0.18 & $\mathrm{Si}$ & 1.4 & $\mathrm{Mn}$ & 21 & $\mathrm{Se}$ & 14 & \\
\hline
\end{tabular}

washed-out soils, such as sandy soils or soil in regions with high precipitation (tropics) show naturally lower concentrations. ${ }^{[4]}$ The soil structure plays an indirect role as compacted soils and a high water table can impair root growth and hence mineral uptake. Minerals need to be solubilised for uptake and hence the chemical composition and metal oxidation state is of utmost importance. Generally, the solubility of metal compounds decreases with increasing soil $\mathrm{pH}$ (soils with high clay content, lime soils or sedimentary rocks have high $\mathrm{pH}$ values) and with increasing phosphate content. Also, the amount of dissolved organic matter (DOM) has an influence; however, depending on the metal ion and the nature of the DOM, either a decrease in solubility due to the formation of insoluble complexes or a mobilisation of originally insoluble minerals can be observed. The importance of the soil condition is well illustrated by the example of zinc. Zinc is a typical micronutritient, which includes essential trace elements such as Mo, V, Mn, or Se as well as more abundant metal ions such as $\mathrm{Fe}$ and $\mathrm{Cu}$ (please note that to facilitate readability, we omit specific oxidation numbers here as different oxidation states are possible). As it is estimated that roughly $50 \%$ of the cereal crops worldwide are grown on soils with low bioavailability of zinc, zinc deficiency in crops, farm animals, and accordingly also in humans is the most common micronutritient deficiency. The effect of soil $\mathrm{pH}$ on solubility of metal ions is best illustrated with $\mathrm{Al}^{3+}$ as an example, commemorated by our first year chemistry class learning about the amphoteric character of aluminium oxide. $\gamma-\mathrm{Al}_{2} \mathrm{O}_{3}$, the most common naturally occurring modification, is insoluble in the $\mathrm{pH}$ range of roughly $5-9$, and hence has a rather low bioavailability. However, it becomes soluble in the form of its aqua complexes below and in the form of its hydroxo complexes above this $\mathrm{pH}$ range. While the mobilisation of $\mathrm{Al}^{3+}$ ions at low $\mathrm{pH}$ is responsible for the typical blue colour of Hydrangea due to formation of $\mathrm{Al}^{3+}$-catecholat complexes of $e . g$. the anthocyanidine delphinidin 3-glucoside (at higher soil $\mathrm{pH}$ values and hence in absence of bioavailable $\mathrm{Al}^{3+}$ the flowers become pink), aluminium rendered bioavailable in acid water is acutely toxic to fish. The influence of the oxidation state on the bioavailability of metal ions is probably shown most dramatically for iron: the solubility products of $\mathrm{Fe}(\mathrm{OH})_{3}$ and $\mathrm{Fe}(\mathrm{OH})_{2}$ are respectively $2.6 \cdot 10^{-39} \mathrm{M}^{4}$ and $4.9 \cdot 10^{-17} \mathrm{M}^{3},{ }^{[5]}$ which gives a solubility of $\left[\mathrm{Fe}^{3+}\right]=2.6 \cdot 10^{-18}$ $\mathrm{M}$ and of $\left[\mathrm{Fe}^{2+}\right]=4.9 \cdot 10^{-3} \mathrm{M}$ at $\mathrm{pH} 7$ and hence an approximately $10^{15}$-fold difference in solubility! Fe was originally present on earth exclusively in the rather well-soluble $\mathrm{Fe}^{2+}$ state and the appearance of the first $\mathrm{O}_{2}$-producing microorganisms some 2.5 billion years ago can be seen as the first global environmental disaster. As we see below, organisms had to become exceptionally creative and resourceful when struggling to mobilise and store essential iron.

Taking a closer look at the composition of the human body (Table 1), the chemical elements can be roughly distinguished into macro- and micronutrients. Elements belonging to the ma- cronutrients are on the one hand $\mathrm{C}, \mathrm{H}, \mathrm{N}, \mathrm{O}, \mathrm{P}$, and $\mathrm{S}$ that build the organic matter (proteins, nucleic acids, lipids, carbohydrates, etc.) and account for $98 \%$ of the body mass including the water content, and on the other hand $\mathrm{Ca}, \mathrm{K}, \mathrm{Na}, \mathrm{Mg}$, and $\mathrm{Cl}$ that are required in quantities too great to be considered micronutrients. The remaining $<2 \%$ comprise 22 elements that belong to the micronutrients. Among these 22 elements are some of the best known metal ions found in metalloenzymes, e.g. Fe, $\mathrm{Zn}$, or $\mathrm{Cu}$. While all the elements listed in Table 1 are found in a human body, not all of them are considered essential - it is still open to debate what role trace amounts of elements like chromium, boron, aluminium, and arsenic fulfil in humans. The latter two have been even linked to cancer in higher, but nevertheless environmentally relevant concentrations. Fig. 1 gives an overview on the elements of life, i.e. which ones are considered essential for all, or most organisms, respectively.

Some elements are considered semi-essential, meaning they are not necessary to sustain life, but are highly beneficial within a narrow limit of daily intake. One such example is fluorine, which is important for dental health and bone strength, hardening the apatite and making it more acid resistant by replacing $\mathrm{OH}^{-}$ by $\mathrm{F}^{-}$ions. ${ }^{[8]}$ Further uses of fluorine are as a chemical defence mechanism by plants against herbivores. They synthesise organofluorines, e.g. fluoroacetate, in rather large amounts, which makes the plant poisonous. ${ }^{[9]}$

Further elements have only recently been discovered to be essential in the kingdoms of life, one example being bromine. Bromide has long been known to be ubiquitous but with no essential function known. It has now recently been found that $\mathrm{Br}^{-}$ is an essential cofactor for tissue development and collagen IV scaffold.[10] In some cases, the essentiality of a certain element has been the matter of debate for many years. One such example is chromium, whose role as a trace element essential for organisms has often been disputed, but the final proof is, to the best of our knowledge, still missing. ${ }^{[11]}$ Nevertheless, even for the essential elements the famous saying by Paracelsus has to be always kept in mind: "All things are poison, and nothing is without poison, the dosage alone makes it so a thing is not a poison." The general difference between a micronutrient and a toxic compound is that for the micronutrient there is a concentration range in which a beneficial effect for the organism is observed. Outside this range there is a negative effect appearing as a deficiency below and toxicity above the beneficial values. Many essential trace elements have beneficial concentration ranges in the lower two-digit $\mathrm{mg}$ range (Fe 8-45 mg, Cu 1-10 mg, Zn 15-40 mg), but for others the beneficial effects are only observed in a very narrow range. An extreme example is selenium: the recommended daily intake (RDI) value for an adult person is $55 \mu \mathrm{g}$, whereas doses above $200 \mu \mathrm{g}$ can already be toxic! In contrast, for non-essential elements there is no such beneficial range. At low concentration there is no effect (beneficial or inhibitory) on the organism, while with increasing 


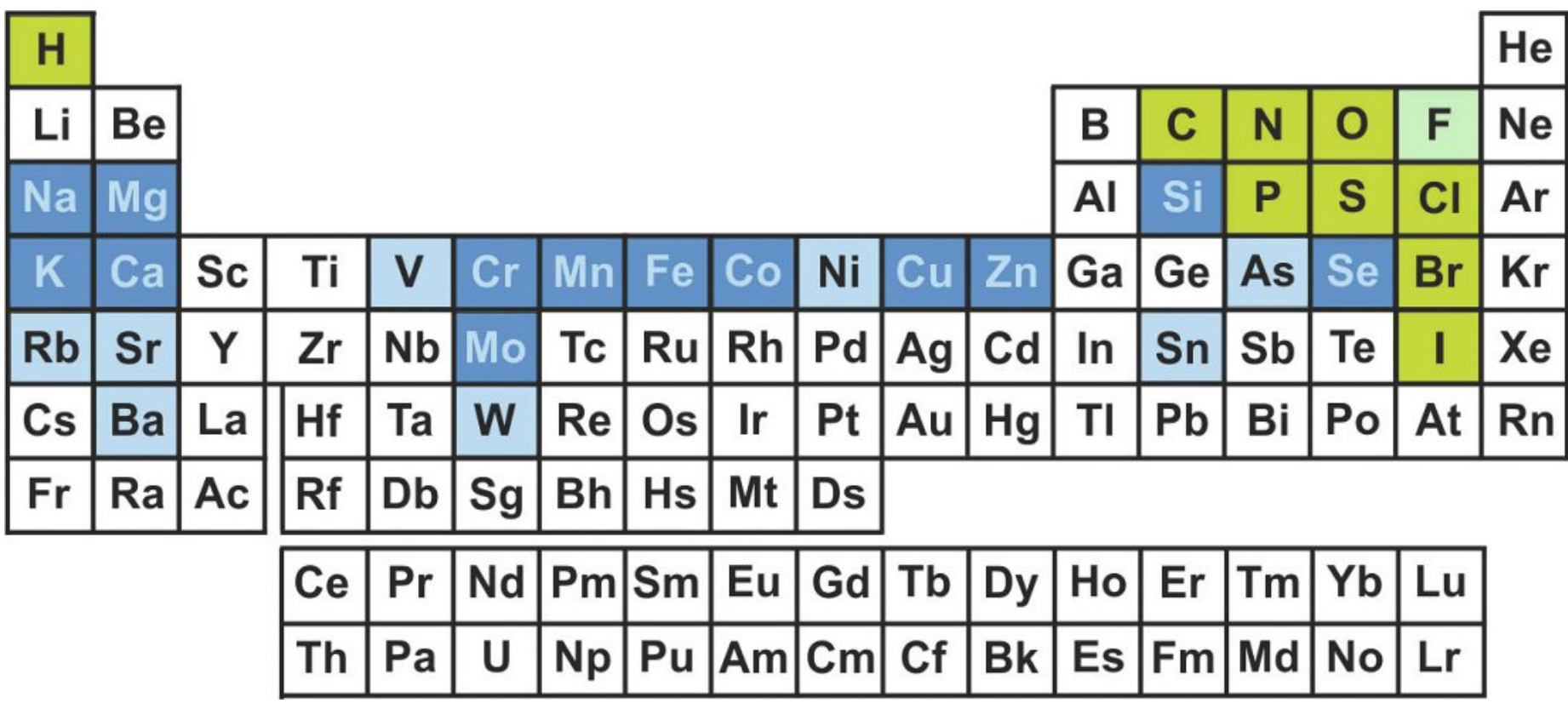

Fig. 1. Periodic Table of the elements with the ions essential for most organisms coloured with a green (non-metals) or blue (metals and half-metals) background. Those elements showing a light green or blue background have been found to be essential either in some organisms and/or are most probably also essential for humans. Figure is adapted from refs [6] and [7].

concentration toxicity occurs. The threshold defining the toxicity depends of course again on the element, its chemical speciation, and probable defence strategies of the organism.

\section{Metal Ions in the Cell}

While a living cell harbours a multitude of different metal ions, only very few are freely available, such as the alkaline metal ions sodium and potassium needed e.g. to maintain osmotic balance or for signal transmission. Most other metal ions are tightly regulated, either because they are extremely precious for the organism because of their low abundance or because their chemical reactivity can potentially be harmful if the metal ion occurs freely at an undesired cellular location. The regulation includes active transport and uptake mechanisms, in which the metal ion remains tightly bound to a ligand or biomacromolecule, e.g. a transport protein. The comparison between intracellular metal ion concentrations and those found in sea water nicely illustrates the selectivity operated by living organisms regarding the sort of metal ions they allow into their cells (Table 2). In the following sections, we summarise briefly the possible roles metal ions fulfil in living organisms.

\subsection{Freely Available Metal lons in the Cell}

Only some alkaline and alkaline earth metal ions are considered to be freely available in the cell, namely $\mathrm{Na}^{+}, \mathrm{K}^{+}, \mathrm{Mg}^{2+}$, and $\mathrm{Ca}^{2+}$ (Table 2). In mammalian cells, it is notable that the concentrations within the cell and in the extracellular space are distinctly different. It should also be mentioned that the concentrations given in Table 2 are not necessarily the concentrations that are freely available. For example, in the case of $\mathrm{Mg}^{2+}$, it is estimated that most of the $\mathrm{Mg}^{2+}$ present is bound rather tightly to the large abundance of phosphate groups within the cell, e.g. of the phospholipids forming the cell wall, the nucleoside triphosphates, and nucleic acids in general. The $30 \mathrm{mM}$ total concentration is thus reduced to just $1-2 \mathrm{mM}$ fully solvated $\mathrm{Mg}^{2+}$ in the cell plasma. Another example is $\mathrm{Ca}^{2+}$. In higher organisms, most $\mathrm{Ca}^{2+}$ is bound within bone material and similar as a phosphate salt, i.e. apatite, with further anions like $\mathrm{OH}^{-}$and/or $\mathrm{F}^{-}$(in teeth). In addition, $\mathrm{Ca}^{2+}$ also is a crucial trigger in chemical synapses to release the effective neurotransmitter within milliseconds into the synaptic cleft.
In contrast, $\mathrm{Na}^{+}$and $\mathrm{K}^{+}$, both present in much higher concentrations respectively in the extracellular and the intracellular space, seem to be mostly important as counter ions for the multitude of negative charges, e.g. in the context of nucleic acids, as well as to keep the ionic strength constant. ${ }^{[17]}$ To be able to maintain a constant concentration of both ions against a concentration gradient, biology has developed highly selective transmembrane proteins transporting these ions actively with the consumption of ATP.

\subsection{Structural Metal lons}

Some metal ions 'solely' serve the purpose of stabilising certain three-dimensional structures of biomolecules. The most prominent examples are certainly nucleic acids. The negatively charged phosphate sugar backbone is mostly associated with alkaline metal ions for charge compensation. This neutralisation of the negative charge is the pre-requisite for the formation of higher order structures that, in the case of RNA, fulfil many active roles in a cell, e.g. as catalytic RNAs (ribozymes), or regulatory RNAs (riboswitches), or others. ${ }^{[18,19]}$ In addition to general charge compensation, $\mathrm{Mg}^{2+}$ particularly also binds to specific local structures, i.e. metal ion binding motifs, in RNA. Such local structures are for example (i) tandem GC base pairs, (ii) GU wobble pairs, (iii) sheared GA base pairs, (iv) the metal-ion zipper, or (v) the $\mathrm{Mg}^{2+}$ clamp. We refrain here from going into further detail, but rather refer to a recent review on metal ion interactions in nucleic acids. [20]

In the case of monovalent ions, G-quadruplex structures are the best known. Originally identified in the telomeres to stabilise the chromosomic ends, a multitude of locations within the genome are known today for both DNA and RNA quadruplex structures. In the case of RNA they rather serve as regulatory elements. While DNA and RNA G-quadruplex structures share the same $G$ quartet structures, distinct differences between the two forms in terms of possible topologies and thermodynamic stability are known. Both types are rather selective for monovalent ions but also divalent metal ions can be accommodated. However, $\mathrm{K}^{+}$seems to be the metal ion of choice as it stabilises the three-dimensional fold best, as it has the perfect size to fit into the void space between two neighbouring quartets and its preferred coordination number allows simultaneous binding of all eight guanine $\mathrm{O6}$ atoms (Fig. 2).[21] 
Table 2. Summary of total concentrations of various metal ions in the ocean, mammalian cells, the extracellular space, as well as bacterial cells. The respective literature source is always given in the title row. Table is reproduced from ref. [12] with permission.

\begin{tabular}{|c|c|c|c|c|c|c|}
\hline $\mathbf{M}^{\mathrm{n}+}$ & $\begin{array}{l}\text { Seawater }^{[13]} \\
{[\mathrm{ppm}]}\end{array}$ & $\begin{array}{l}\text { Seawater }^{[14]} \\
{[\mathrm{mM}]}\end{array}$ & $\begin{array}{l}\text { Mammalian } \\
\text { cell }^{[14]}[\mathrm{mM}]\end{array}$ & $\begin{array}{c}\text { Extracellular } \\
\text { space }^{[14]}[\mathrm{mM}]\end{array}$ & $\begin{array}{c}\text { Bacterial cell }^{[15]} \\
{[\mathrm{mg} / \mathrm{kg}]}\end{array}$ & $\begin{array}{c}\text { Bacterial } \\
\text { cytosol }^{[16]}[\mathrm{mM}]\end{array}$ \\
\hline $\mathrm{Li}^{+}$ & 0.17 & & & & & \\
\hline $\mathrm{Na}^{+}$ & $1.1 \cdot 10^{4}$ & 470 & 10 & 145 & $4.6 \cdot 10^{3}$ & \\
\hline $\mathrm{K}^{+}$ & $3.9 \cdot 10^{2}$ & 10 & 140 & 5 & $115 \cdot 10^{3}$ & $>10$ \\
\hline $\mathrm{Rb}^{+}$ & 90 & & & & & \\
\hline $\mathrm{Cs}^{+}$ & 3 & & & & & \\
\hline $\mathrm{Be}^{2+}$ & $6 \cdot 10^{-7}$ & & & & & \\
\hline $\mathrm{Mg}^{2+}$ & $1.35 \cdot 10^{3}$ & 50 & $30^{\mathrm{a}}$ & 1 & $7 \cdot 10^{3}$ & $>10$ \\
\hline $\mathrm{Ca}^{2+}$ & $4.1 \cdot 10^{2}$ & 10 & 1 & 4 & $5.1 \cdot 10^{3}$ & 0.1 \\
\hline $\mathrm{Sr}^{2+}$ & 375 & & & & & \\
\hline $\mathrm{Ba}^{2+}$ & 425 & & & & & \\
\hline $\mathrm{Cr}^{2+}$ & $5 \cdot 10^{-4}$ & & & & 4 & \\
\hline \multicolumn{7}{|l|}{$\mathrm{Cr}^{3+}$} \\
\hline $\mathrm{Mn}^{2+}$ & $2 \cdot 10^{-3}$ & & & & 260 & $10^{-2}$ \\
\hline $\mathrm{Fe}^{2+}$ & $3 \cdot 10^{-3}$ & $1 \cdot 10^{-4}$ & & & 170 & 0.1 \\
\hline \multicolumn{7}{|l|}{$\mathrm{Fe}^{3+}$} \\
\hline $\mathrm{Co}^{2+}$ & $4 \cdot 10^{-4}$ & $3.1 \cdot 10^{-6}$ & & & 7.5 & low \\
\hline \multicolumn{7}{|l|}{$\mathrm{Co}^{3+}$} \\
\hline $\mathrm{Ni}^{2+}$ & $7 \cdot 10^{-3}$ & $1 \cdot 10^{-6}$ & & & & low \\
\hline $\mathrm{Cu}^{+}$ & & & & & & $10^{-2}$ \\
\hline $\mathrm{Cu}^{2+}$ & $3 \cdot 10^{-3}$ & $1 \cdot 10^{-3}$ & & & 150 & \\
\hline $\mathrm{Zn}^{2+}$ & $1 \cdot 10^{-2}$ & $1 \cdot 10^{-4}$ & & & 83 & 0.1 \\
\hline $\mathrm{Ru}^{3+}$ & $1 \cdot 10^{-2}$ & & & & & \\
\hline $\mathrm{Pd}^{2+}$ & $1 \cdot 10^{-2}$ & & & & & \\
\hline $\mathrm{Ag}^{+}$ & $7 \cdot 10^{-2}$ & & & & & \\
\hline $\mathrm{Cd}^{2+}$ & 0.2 & & & & 31 & \\
\hline $\mathrm{Pt}^{2+}$ & $1 \cdot 10^{-2}$ & & & & & \\
\hline $\mathrm{Au}^{3+}$ & $4 \cdot 10^{-3}$ & & & & & \\
\hline $\mathrm{Hg}^{2+}$ & $8 \cdot 10^{-2}$ & & & & & \\
\hline $\mathrm{Tl}^{+}$ & 0.5 & & & & & \\
\hline $\mathrm{Pb}^{2+}$ & 13 & & & & & \\
\hline
\end{tabular}

aThe free concentration of $\mathrm{Mg}^{2+}$ is about $1 \mathrm{mM}$.

Metal ions can also play a structural role in metalloproteins, either bound directly to amino acid side chains, or bound to a cofactor. One prominent example is chlorophyll with its central $\mathrm{Mg}^{2+}$ ion. $\mathrm{Mg}^{2+}$ can also be replaced with other divalent metal ions, but at the cost of activity of the entire photosystem. ${ }^{[22]} \mathrm{Mg}^{2+}$ fine-tunes the electronic properties of the chlorophyll ligand in order to enable a most efficient energy transfer. A paramagnetic metal ion, for example, would simply quench the chlorophyll fluorescence.
An important structural element in a different sense is silicon. The best known organisms that use silicon are maybe diatoms, a major group of algae that generate about $20 \%$ of the oxygen produced worldwide by photosynthesis. Diatoms build intricate hard but porous cell walls composed primarily of $\mathrm{SiO}_{2}$. Another example is the plant rough horsetail, or scouring rush, which incorporates silicate instead of lignin into its cell wall (up to 7\%) to reach a higher stability. The German name Zinnkraut ('tin-herb') indicates its former use as abrasive material for cleaning cooking 


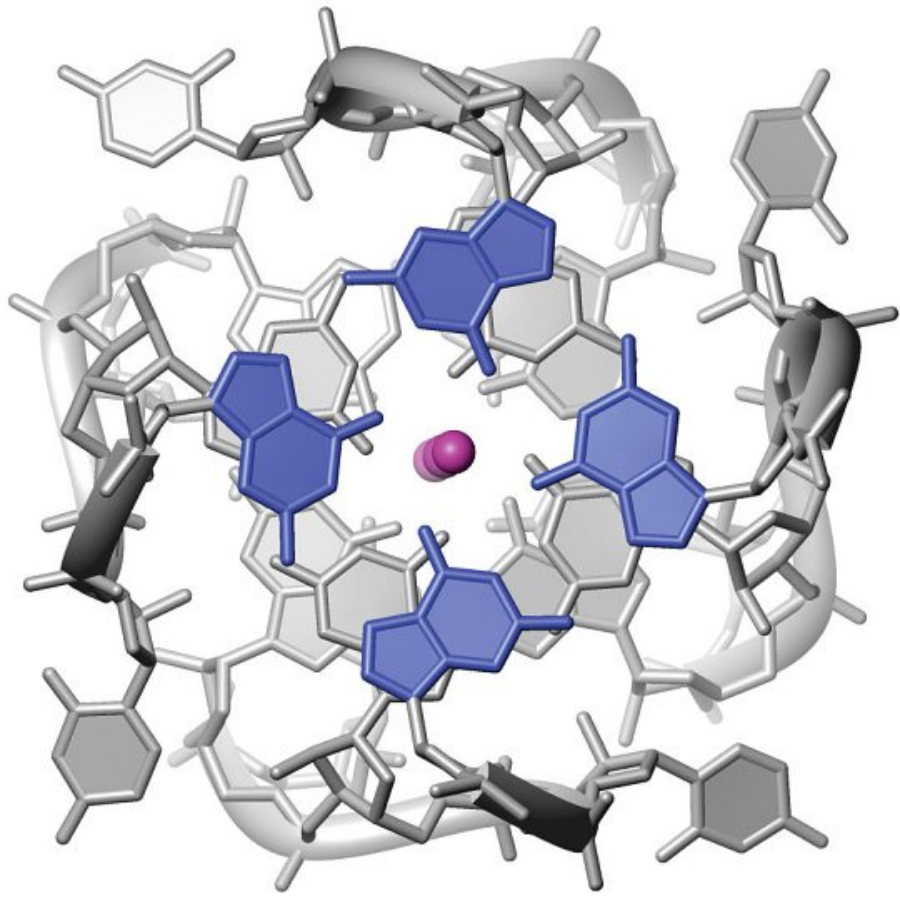

Fig. 2. G-quadruplex structure shown from the top with the coordinating fully dehydrated $\mathrm{K}^{+}$ions lined up along the central axis. This Figure is based on the PDB file 1P79 and is reproduced from ref. [20] with permission.

ware made of tin. Higher organisms from other kingdoms of life, e.g. humans, use silicon for similar purposes: several tissues like nails and connective tissues, but also bone, cartilage, blood vessels, and tendons are strengthened considerably by the incorporation of silicon molecules.

\subsection{Metalloenzymes}

Enzymes are generally divided into six classes; (i) Oxidoreductases, that transfer electrons from one molecule to another, (ii) Transferases, that enable the specific transfer of a functional group from one molecule to another, (iii) Hydrolases, that use a water molecule to break down a chemical bond, i.e. hydrolysis, (iv) Lyases, that break chemical bonds by other means than hydrolysis, (v) Isomerases, that convert a molecule from one isomer to another, and (vi) Ligases, that catalyse the joining of two molecules resulting in a chemical bond, which often involves hydrolysis of the functional group on one of the two biomolecules. Innumerable enzymes are actually metalloenzymes, the nature of the metal ions being dependent on the type of reaction as well as the functional groups involved. However, it is remarkable that, for instance, $\mathrm{Mn}^{2+}$-containing enzymes from all six classes are known. For an overview on metalloenzymes, we refer to two Handbooks on Metalloproteins, ${ }^{[23]}$ which provide the interested reader with a wealth of information as a starting point, and/or the series Metal Ions in Life Sciences. ${ }^{[24]}$ Here, we want to concentrate on two classes only, which are usually considered $T H E$ classical metalloenzymes.

\subsubsection{Oxidoreductase Enzymes}

Oxidoreductases are a very large group of enzymes that transfer electrons from an electron donor, the reductant, to an electron acceptor, the oxidant. They usually employ cofactors and can also create electron transport chains, e.g. across membranes. This large class of enzymes can be divided further into 22 subclasses, depending on the nature of the donor, the acceptor, the cofactor and/or the reactant. As a comprehensive overview would be far too extensive, we only mention two examples.

Alcohol oxidoreductases include alcohol dehydrogenases, which catalyse the interconversion between primary and second- ary alcohol functional groups and aldehydes or ketones, respectively, by using nicotinamide adenine dinucleotide $\left(\mathrm{NAD}^{+}\right)$as the cofactor and electron acceptor. Mammalian alcohol dehydrogenases harbour two $\mathrm{Zn}^{2+}$ ions, one in the active site coordinating the substrate and thereby activating it by its Lewis acidity, and a second structural $\mathrm{Zn}^{2+}$, which is important for protein stability.[23]

A key enzyme for all living organisms is ribonucleotide reductase (RNR), which converts ribonucleotides into 2'-deoxyribonucleotides needed for DNA synthesis. ${ }^{[25,26]}$ Three classes of RNRs are known, all of which display a similar mechanism of reduction using free-radical chemistry, but employ different strategies for radical production. Class I RNRs use a ferrous/ferric conversion to generate a tyrosyl radical, class II use coenzyme $\mathrm{B}_{12}$, and class III S-adenosyl methionine (SAM) together with an iron-sulphur centre.

\subsubsection{Hydrolase Enzymes}

Hydrolysis describes the cleavage of a covalent bond under consumption of water, adding a proton to one and a hydroxide to the other fragment. 13 subclasses of hydrolases have been defined, depending on the bonds they act upon. In metal-dependent hydrolases generally, but not exclusively, one (or two) divalent metal ions $\left(\mathrm{Mg}^{2+}, \mathrm{Zn}^{2+}, \mathrm{Fe}^{2+}, \mathrm{Mn}^{2+}\right.$, etc. $)$ act as Lewis acids to activate a coordinated water molecule or to generate a hydroxo group. For example, nucleases, phosphodiesterases, and phosphatases act on esters, DNA glycosylase acts on sugar, and proteases and peptidases act on peptide bonds. Further substrates include $\mathrm{C}-\mathrm{C}$, $\mathrm{C}-\mathrm{N}, \mathrm{C}-\mathrm{P}, \mathrm{S}-\mathrm{S}$, and other bonds. Again, also here, only a few prominent examples are mentioned.

Phosphodiester formation and cleavage as well as the related meta-phosphate cleavage are crucial reactions in every organism and include ATP hydrolysis by ATPases, DNA strand cleavage by restriction enzymes, oligonucleotide ligation by ligases, DNA or RNA strand formation by the respective polymerases, or ribozyme cleavage reactions, to name just a few. Such reactions are often dominated by a so-called two-metal ion mechanism. This mechanism has been put forward first for ATP hydrolysis as well as enzyme kinetics. ${ }^{[27-30]}$ Hydrolysis of adenosine 5'-triphosphate (ATP), i.e. the cleavage of the phosphoanhydride bond, is probably one of the most common reactions in life, transforming chemical energy for example into mechanical energy, i.e. in muscles. At the same time, ATP is also a building block for RNA oligonucleotide synthesis, i.e. transcription by polymerases. In both reactions, two $\mathrm{Mg}^{2+}$ ions are directly involved, both coordinating the triphosphate chain. However, their coordination pattern is different and dependent on the protein active site: in the case of ATPases, one $\mathrm{Mg}^{2+}$ is coordinated to the $\gamma$ phosphate, and the second to the $\alpha$ and $\beta$ phosphates (next to further coordination sites), resulting in the release of ortho-phosphate and adenosine 5'-diphosphate (ADP). In polymerases, the first $\mathrm{Mg}^{2+}$ is $\beta, \gamma$ coordinated and the second $\alpha$ coordinated, resulting in the release of a diphosphate group and the incorporation of the nucleoside monophosphate into the growing oligonucleotide chain.

In oligonucleotide cleavage reactions, e.g. self-cleavage by ribozymes, the two metal ions are coordinated to the cleavable phosphodiester, as well as the incoming nucleophile (Fig. 3). The two (or sometimes three) metal ions on the one hand activate the nucleophile and on the other hand stabilise the transition state with its additional negative charge as well as the leaving group. Using the well investigated group I intron as an example (Fig. 3), metal ion $M_{A}$ coordinates and thus stabilises the 3'-oxygen of the leaving group and $\mathrm{M}_{\mathrm{B}}$ activates the nucleophilic 3'-oxygen of the exogenous GMP. The third ion $\mathrm{M}_{\mathrm{C}}$ activates the nucleophilic 2'-oxygen of the exogenous GMP, the usage of this nucleotide being a specialty of group I introns. Concomitantly, $\mathrm{M}_{\mathrm{A}}$ and $\mathrm{M}_{\mathrm{C}}$ coordinate the pro- $S_{\mathrm{P}}$ oxygen of the scissile phosphodiester (see ref. [20] and refs therein). 


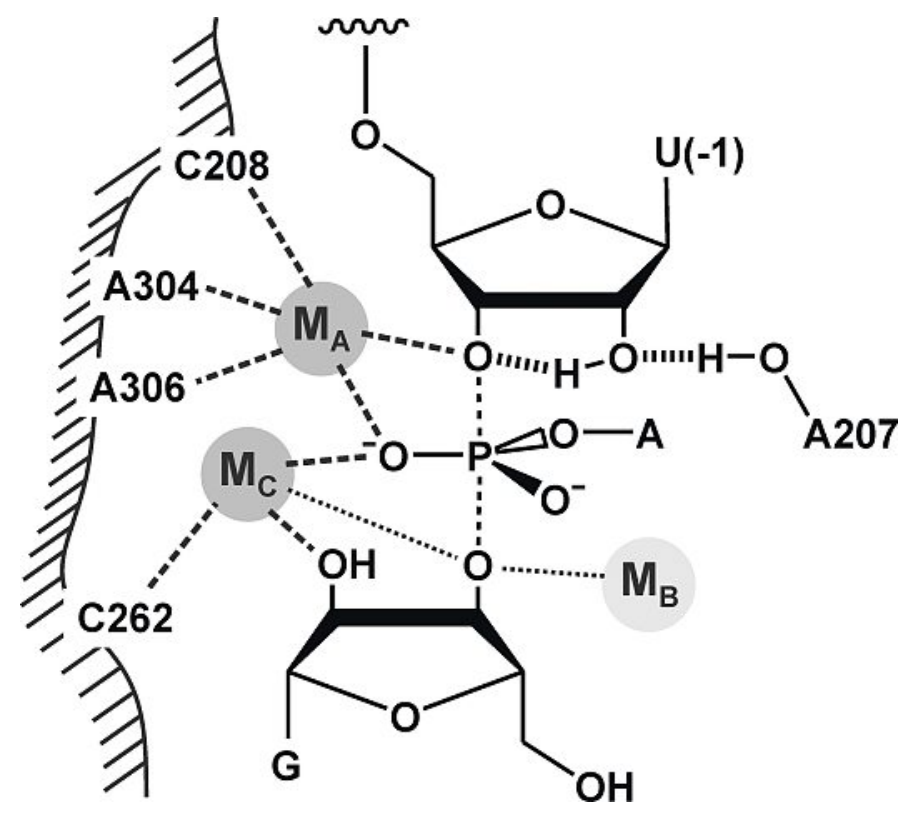

Fig. 3. 'Two'-metal ion mechanism as proposed for group I intron splicing. $M_{A}$ and $M_{C}$ both stabilise the transition state and $M_{A}$ is additionally responsible for stabilising the leaving group. The Figure is reproduced from ref. [20] with permission. For more details, see refs therein.

Another class of hydrolytic enzymes cleaving phosphate monoesters or amide substrates are purple acid phosphatases (PAP). ${ }^{[31]}$ These enzymes have rather diverse biological roles, which include iron transport, immune response by creating reactive oxygen species, and bone resorption. PAPs are highly conserved in eukaryotes and plants but share only $20 \%$ sequence homology between the two kingdoms of life. Their catalytic core consists of a two-metal centre, one $\mathrm{Fe}^{3+}$ and a second metal ion $\mathrm{M}^{2+}$, which is either $\mathrm{Fe}^{2+}$ (in animals) or $\mathrm{Zn}^{2+} / \mathrm{Mn}^{2+}$ in plants respectively (Fig. 4). The hydrolytic cleavage of the phosphate monoester does not alter the redox states of the metal ions. However, PAPs can also perform peroxidation reactions, i.e. they are also oxidoreductive enzymes, whereby the redox active $\mathrm{Fe}^{2+/ 3+}$ ions change their oxidation states.

\section{Metal Ion Homeostasis}

For each essential metal ion there is an optimal concentration range that is crucial for life. ${ }^{[32]}$ This is achieved through tightly regulated processes for uptake, storage, and secretion that are embraced under the term homeostasis. The difference between a metal ion that is under homeostatic control and one that is not

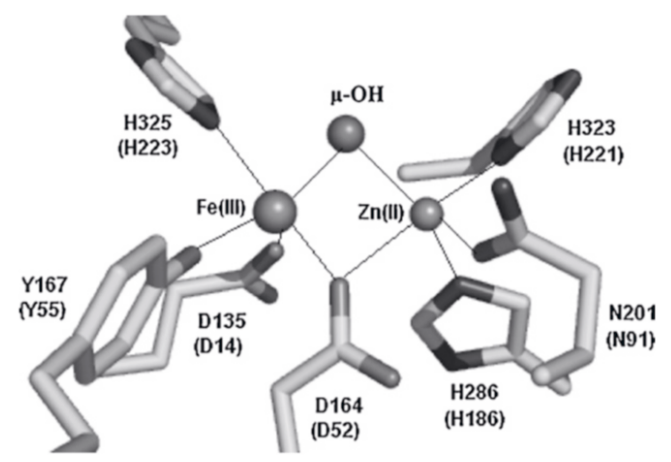

Fig. 4. The active site of all known PAPs is highly conserved and harbours a $\mathrm{Fe}^{3+}$ coordinated to an invariant tyrosine. The ligand to metal charge transfer transition is the origin of the characteristic purple colour. The divalent metal ion can be either $\mathrm{Zn}^{2+}, \mathrm{Mn}^{2+}$, or $\mathrm{Fe}^{2+}$. The metal ion shown bridging hydroxide is proposed to be the hydrolysis-initiating nucleophile. The Figure is reproduced from ref. [31] with permission. was quite plausibly shown with an experiment that analysed the total metal ion concentrations of earthworms (Eisenia andrei) that were cultivated on metal ion-containing soils. ${ }^{[33]}$ While internal concentrations of $\mathrm{Cu}^{\mathrm{n}+}$ and $\mathrm{Zn}^{2+}$ reached a steady state that was maintained for the entire study period of 2 months within the first day of exposure, the $\mathrm{Cd}^{2+}$ concentration increased continuously with time. That was taken as a clear indication that the two essential elements $\mathrm{Cu}^{\mathrm{n}+}$ and $\mathrm{Zn}^{2+}$ are actively regulated, starting with an active uptake to reach the optimal concentration range quickly and then keeping a delicate balance between uptake and excretion. It is further fascinating that variations of the soil metal ion concentrations by a factor of $100\left(\mathrm{Cu}^{\mathrm{n}+}\right)$ or $590\left(\mathrm{Zn}^{2+}\right)$ only resulted in the variation of the internal concentrations by a factor of 5. In contrast, for $\mathrm{Cd}^{2+}$ no such homeostatic mechanisms seem to exist. This does not mean, however, that the organism is flushed uncontrolled with a potentially toxic metal ion and it is not unlikely that the internalised $\mathrm{Cd}^{2+}$ is bound in form of stable and hence non-toxic $\mathrm{Cd}^{2+}$ complexes, e.g. Cd-metallothioneins, or stored within vesicles. Interestingly, also for $\mathrm{Pb}^{2+}$ such a fast uptake to a steady state concentration was observed. Assuming the absence of any essentiality for $\mathrm{Pb}^{2+}$, this illustrates well that other metal ions can invade specific homeostatic systems if they are chemically and size-wise similar enough, e.g. $\mathrm{Pb}^{2+}$ and $\mathrm{Zn}^{2+}$.

The study and understanding of metal ion homeostasis is complicated further by the fact that in multi-cell organisms such as humans, different optimal concentration ranges for a given metal ion exist and in addition, even enzymes in different cellular compartments can have quite different requirements. In humans, currently 14 different transmembrane transporters are known that are responsible for $\mathrm{Zn}^{2+}$ influx into the cytosol (ZIP family) and ten are known for $\mathrm{Zn}^{2+}$ efflux (ZnT family). ${ }^{[34]}$ Concerning the controlled transport within the cytosol, $\mathrm{Zn}^{2+}$ is certainly less problematic compared to redox active metal ions such as $\mathrm{Cu}^{+/ 2+}$ or $\mathrm{Fe}^{2+/ 3+}$ but free $\mathrm{Zn}^{2+}$ concentrations are still kept low using metallothioneins, small cysteine-rich proteins, as cellular transporters. $\mathrm{Zn}^{2+}$ is then released at or close to the target $\mathrm{Zn}^{2+}$-requiring enzyme and the metal ion will find its designated binding site more or less on its own. In contrast, for, e.g. redox active $\mathrm{Cu}$, organisms have evolved more sophisticated systems that are denoted $\mathrm{Cu}$-chaperones. ${ }^{[35]}$ Different chaperones exist depending on the target enzyme or transmembrane transporter, e.g. Atox 1 for $\mathrm{Cu}$-transport to the trans-Golgi-network, Cox 17 for delivery to the mitochondria, or $\mathrm{Ccs}$ for the loading of superoxide dismutase (SOD) with $\mathrm{Cu}$. All three chaperones have in common that they form heterodimers with their target proteins and ensure a controlled transfer of the $\mathrm{Cu}$ ion to its target location. At no time is the $\mathrm{Cu}$ ion released freely to the cytosol but coordinated constantly either by residues (mostly cysteines) of the chaperone or the target protein or both.

We will now shortly sketch the different protagonists and their roles in the human iron homeostatic system. As a basic principle, iron transport across membranes always occurs in the ferrous $\left(\mathrm{Fe}^{2+}\right)$ state, while for transport and storage only the ferric state $\left(\mathrm{Fe}^{3+}\right)$ is observed. Intestinal absorption can follow three different pathways: (i) direct absorption of $\mathrm{Fe}^{2+}$-heme by the $\mathrm{HCP}-1$ transporter, as well as two pathways for 'inorganic' iron that are (ii) the specific multi-protein complex consisting of integrin (uptake of $\mathrm{Fe}^{3+}$ ), paraferritin (reduction to $\mathrm{Fe}^{2+}$ ), and mobilferrin (release to the cytosol) and (iii) transport via the universal divalent metal ion transporter DMT1 that requires prior reduction to ferrous iron by e.g. dietary ascorbic acid. ${ }^{[36]}$ The transmembrane transporter ferroportin is responsible for iron release from the intestinal cell into the bloodstream. Exported $\mathrm{Fe}^{2+}$ is directly oxidised by a ferrioxidase and bound to transferrin (TF), the main Fe-transporter in the serum. TF contains two $\mathrm{Fe}^{3+}$ binding sites, one each in the nearly identical $\mathrm{N}$ - and C-lobes of the protein. ${ }^{[37]} \mathrm{Fe}^{3+}$ coordination to $\mathrm{TF}$ is a classic example of a synergistic binding mode: first, binding of a synergistic $\mathrm{CO}_{3}^{2-}$ to $\mathrm{TF}$ is required, followed by $\mathrm{Fe}^{3+}$ binding to this 
carbonate ion and completion of the octahedral coordination sphere by residues of the TF protein (Fig. 5A). To ensure the absence of any free $\mathrm{Fe}^{3+}$ ions in the serum, enough TF is produced so that only $1 / 3$ of all Fe-binding sites are occupied at each time. Iron transport into the cell proceeds via receptor mediated endocytosis. The association constant between TF and its receptor varies with the TFiron load: it is highest for $\mathrm{Fe}_{2} \mathrm{TF}$, followed by FeTF and lowest for apo- and hence metal-free TF. ${ }^{[38,39]}$ This ensures that the receptor is not blocked by (useless) apo-TF and iron is most efficiently taken up by the cell. But the chemically absolutely fascinating journey continues with another trick, the efficient, but extremely resourceful intracellular iron release from TF: after endocytosis of the $\mathrm{Fe}_{2} \mathrm{TF}$ complex, the $\mathrm{pH}$ within the vesicle is lowered, leading to protonation of the synergistic carbonate and hence weakening of the binding. ${ }^{[40,41]}$ An additional reduction of $\mathrm{Fe}^{3+}$ to $\mathrm{Fe}^{2+}$ completely releases the iron. ${ }^{[41]}$ The vesicle with the now empty apo-TF is transported back to the outer cell membrane and TF is released back into the serum. In this way, one TF molecule can undergo approximately 100 cycles before degradation occurs. ${ }^{[42]} \mathrm{A}$ few words about iron storage. Effective iron storage is ensured by a multi-subunit protein known as ferritin. Ferritins are evolutionary very old proteins, conserved among all mammalians, plants, bacteria, etc. 24 subunits of 175 amino acids length each form a soluble ball-like protein shell that encloses a cavity of $\sim 80 \AA$ diameter. Within this cavity iron is stored in the $\mathrm{Fe}^{3+}$ oxidation state in form of a Fe $\mathrm{O}_{3}\left(\mathrm{H}_{2} \mathrm{O}\right)_{\mathrm{n}}$ core of $\leq$ 4'500 iron atoms (usually $\sim 1$ '200). Pores within the protein shell allow for iron uptake and release (Fig. 5B). ${ }^{[43]}$

The gene regulation of ferritin and the transferrin receptor is another glorious evolutionary story with no-waste strategy: Socalled iron regulatory proteins (IRPs) coordinate to certain mRNA stem loops in their low iron-containing form. ${ }^{[44]}$ In the ferritin-mRNA this stem loop is located upstream of the sequence and hence IRP binding blocks ferritin translation. In the TF-receptormRNA this stem loop is located downstream and, in this way, stabilises the mRNA against degradation. Both blocking ferritin production and stabilising the TF-receptor-mRNA for increased receptor production are desired processes at low iron status in order to increase the available concentrations of intracellular iron. At high iron concentration, a [4Fe-4S] cluster is formed in the IRP leading to a conformational change and the IRP-stem loop binding is weakened. Ferritin translation occurs and TF-receptor production stalls, both ideal mechanisms to cope with high iron status. The modified IRP, nevertheless, does not become useless, but gains a second life as an aconitase, an enzyme that catalyses the isomerisation of citrate to isocitrate.

\section{Elements of Life and Death}

Luckily, not only the essential, but also the non-essential or even toxic elements generally have a rather low (bio)availability. In addition, if there is no suitable uptake mechanism, undesired elements are excluded from entry into the organism. There are of course exceptions, lipophilic compounds such as organic mercury or arsenic compounds are absorbed through membranes/skin, volatile substances $(\mathrm{Hg})$ or dust $(\mathrm{Cd}$ has rather low melting and boiling temperatures and can be released into the environment via industrial exhausts - and shows also significant concentrations in tobacco smoke) can be inhaled and enter the body or harm the lungs. Other elements sneak in through homeostatic processes due to their similarity to essential elements $\left(\mathrm{Tl}^{+}\right.$is similar to $\mathrm{K}^{+}, \mathrm{Pb}^{2+}$ and $\mathrm{Cd}^{2+}$ to $\mathrm{Ca}^{2+}$ and $\mathrm{Zn}^{2+}, \mathrm{CrO}_{4}{ }^{2-}$ to $\mathrm{SO}_{4}^{2-}$, etc.). Again, we will just highlight on a few examples how elements of life can turn out to be elements of death when confused by the organism.

One of these elements is thallium (Tl). ${ }^{[45]}$ Thallium is not particularly rare, however, it is largely found as an impurity in potassium-containing minerals and hence the natural exposure is low. $\mathrm{Tl}^{+}$is very similar to $\mathrm{K}^{+}$in terms of ionic radius (but can be oxidised to $\mathrm{Tl}^{3+}$ which is nevertheless not physiologically relevant) and forms the only known well soluble heavy metal carbonate. In contrast, the halides are more similar to the related silver compounds. $\mathrm{Tl}_{2} \mathrm{SO}_{4}$ is a very effective rat poison and as such also linked to intoxication cases in humans, be it accidental, suicidal or with a homicidal intention. In terms of mg amounts required, $\mathrm{Tl}_{2} \mathrm{SO}_{4}$ is comparable to potassium cyanide $(\mathrm{KCN})$ and shares similar popularity in particular due to the absence of taste or odour. Owing to its similarity to $\mathrm{K}^{+}$, thallium(I) is quickly absorbed through the gastrointestinal system and, aided by the $\mathrm{Na}^{+} /$ $\mathrm{K}^{+}$pumps, distributed throughout the entire body. Excretion is hindered by the enterohepatic cycle, hence, after detoxification via the liver and excretion via the bile, $\mathrm{Tl}^{+}$is reabsorbed in the gut. $\mathrm{Tl}^{+}$affects numerous metabolic processes that require $\mathrm{K}^{+}$and causes irreversible damage to the nervous system. All in all, there is no effective detoxification strategy of the human body against thallium(I): on the one hand it is not 'easy' because $\mathrm{Tl}^{+}$is such a good mimic of essential $\mathrm{K}^{+}$, on the other hand there was no evolutionary necessity, other than human stupidity, to develop a sophisticated strategy to ensure survival. This is in contrast to the next example we will discuss.

Cadmium occurs almost exclusively together with zinc minerals (calamine $=\mathrm{ZnCO}_{3} / \mathrm{Zn}_{4}\left[(\mathrm{OH})_{2} \mathrm{Si}_{2} \mathrm{O}_{7}\right] \cdot \mathrm{H}_{2} \mathrm{O}$ ) and hence, despite its low abundance, it is present ubiquitously in nature. ${ }^{[45,46]}$ Man-made exposure includes release into the environment as a

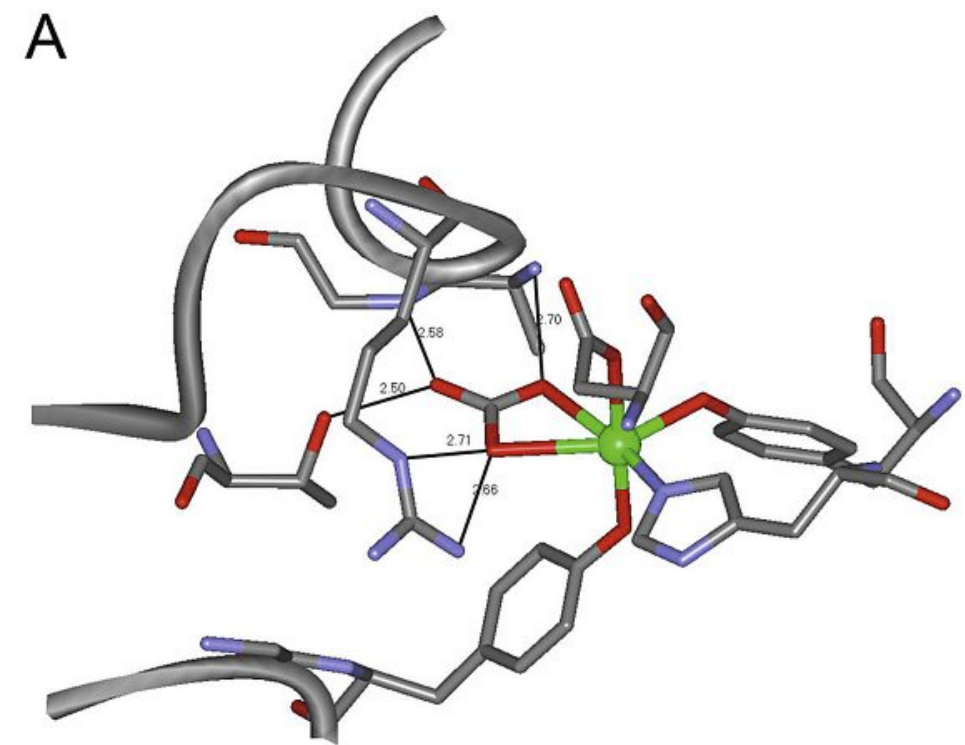

B

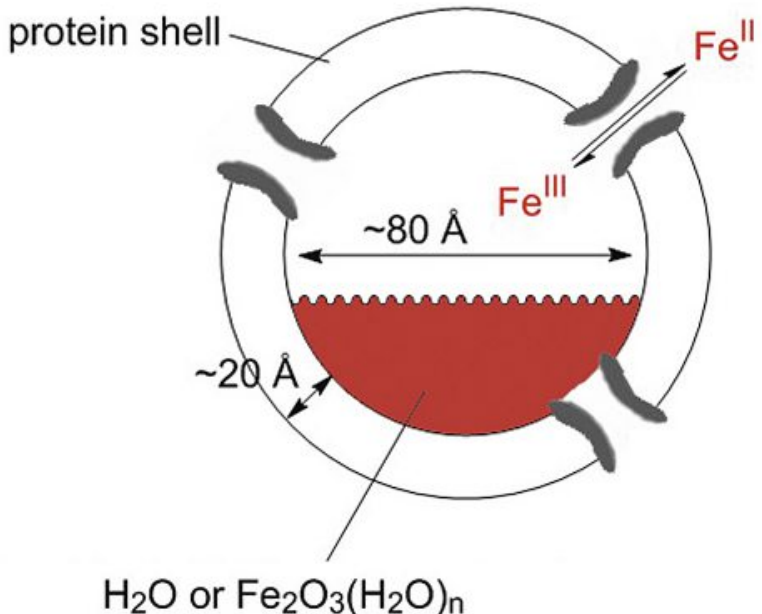

Fig. 5. (A) Active site of human serum transferrin, N-lobe (PDB ID 1N84). (B) Scheme of ferritin molecule. 
by-product of zinc mining, Ni-Cd rechargeable batteries, use as pigments (cadmium-yellow ( $\mathrm{CdS})$ and cadmium red $(\mathrm{Cd}(\mathrm{S}, \mathrm{Se}))$, in alloys, tobacco smoke, and large area use of phosphate fertilizers. The latter are produced in large scale from natural $\mathrm{Ca}_{3}\left(\mathrm{PO}_{4}\right)_{2}$ deposits, and due to the similarity of $\mathrm{Cd}^{2+}$ not only to $\mathrm{Zn}^{2+}$ but also to $\mathrm{Ca}^{2+}$, values of up to $200 \mathrm{mg} \mathrm{Cd}$ per $\mathrm{kg}$ ' $\mathrm{P}_{2} \mathrm{O}_{5}$ ' have been determined depending on the geographic location of the phosphate deposit. As $\mathrm{Cd}^{2+}$ is taken up readily by plants, cadmium uptake by food is the most significant source for humans. Certain plants such as cereals, the cacao tree (dark chocolate can contain up to $0.5 \mathrm{mg} \mathrm{Cd}$ per $\mathrm{kg}$ ), ${ }^{[47]}$ and leafy vegetables (spinach, celery, but also tobacco) as well as mushrooms accumulate cadmium to an even higher extent. $\mathrm{Cd}^{2+}$ is taken up readily in the gastrointestinal tract, but in the liver and kidney it is captured by cysteinerich small proteins, the metallothioneins (MTs). In human body cells, MTs occur as $\mathrm{Zn}_{7} \mathrm{MT}$ complexes, in which the $\mathrm{Zn}^{2+}$ ions are coordinated in form of metal-thiolate clusters. $\mathrm{Zn}^{2+}$ is readily replaced by $\mathrm{Cd}^{2+}$ due to the higher thiophilicity of cadmium. The released $\mathrm{Zn}^{2+}$ ions, and not the $\mathrm{Cd}^{2+}$ itself (!), induce additional MT production. The resulting Cd-MT complexes are stored in the kidney within nuclear inclusion bodies having a half life of approximately 30 years. Accordingly, intestines such as ox liver and in particular kidney can also contain more than $0.5 \mathrm{mg} \mathrm{Cd}$ per $\mathrm{kg}$ fresh weight. This natural detoxification system was discovered 60 years ago, when, during the search for a native $\mathrm{Cd}$-containing protein, a mixed $\mathrm{Zn} / \mathrm{Cd}-\mathrm{MT}$ form was isolated from equine renal cortex. ${ }^{[48]}$ However, despite this detoxification system, cadmium is reported to be carcinogenic and cause nephrotoxicity. Another severe effect is bone softening. This extremely painful disease was first described primarily in women over 40 years of age with already existing calcium and vitamin D deficiency in the district of Toyama, Japan, in 1950 and named Itai-Itai-disease ('ouchouch-disease'). The population had been exposed for years to cadmium-polluted water from mining activities which was used for drinking and irrigating rice fields and fish from the polluted river was a major food source. $\mathrm{Cd}^{2+}$ affects, among other things, the intestinal $\mathrm{Ca}^{2+}$ uptake and the body attempts to cope with the resulting $\mathrm{Ca}^{2+}$ deficiency by mobilising $\mathrm{Ca}^{2+}$ from the bones. Hence women with a predisposition to $\mathrm{Ca}^{2+}$ deficiency were particularly affected. Last but not least, $\mathrm{Cd}^{2+}$ can replace $\mathrm{Zn}^{2+}$ in certain enzymes because of its higher thiophilicity, however, as it has a lower Lewis acidity, the enzymatic activity is reduced, or the enzyme even completely inhibited. One very illustrative example for this is the only functional and natively occurring $\mathrm{Cd}^{2+}$-containing enzyme known, a carbonic anhydrase from the diatom Thalassiosira weissflogii (Fig. 6). ${ }^{[49]}$ Under low $\mathrm{Zn}^{2+}$ conditions, this diatom can use $\mathrm{Cd}^{2+}$ instead, although with a slightly reduced activity of the enzyme.

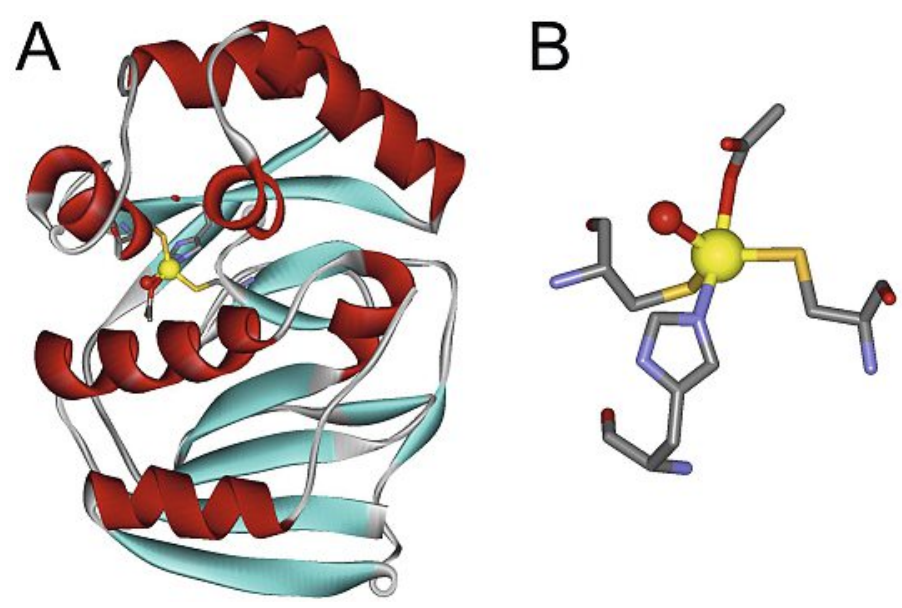

Fig. 6. (A) $\mathrm{Cd}^{2+}$-containing carbonic anhydrase from T. weissflogii (PDB ID 3UK8). (B) Detail of the $\mathrm{Cd}^{2+}$ coordination mode in the active site.
Another heavy metal ion with rather high environmental exposure levels is lead. ${ }^{[50]}$ Like $\mathrm{Cd}^{2+}, \mathrm{Pb}^{2+}$ shows similarities to both $\mathrm{Ca}^{2+}$ and $\mathrm{Zn}^{2+}$. Lead is used in alloys, car batteries, as pigments (red lead $\left(\mathrm{Pb}_{3} \mathrm{O}_{4}\right)$ as anti-corrosion paint, opaque white $\left(\mathrm{Pb}\left(\mathrm{CO}_{3}\right)_{2}\right)$, chromium yellow $\left.\left(\mathrm{PbCrO}_{4}\right)\right)$, in crystal glass, until approximately 1970 in pipes for drinking water, pottery glazing, and in form of tetraethyl lead as antiknock additive (until 1988). Switzerland in particular has an additional problem with its numerous communal shooting ranges that, until recently, were built without any protection against lead leaking from the ammunition into the ground water, now requiring very costly clean-up activities. The roughly 20 tons of lead per year released into the environment from lead ammunition used by hunters in Switzerland are also not to be neglected. Campaigns to promote lead-free ammunition have so far only been partially effective.

$\mathrm{Pb}^{2+}$ is absorbed readily in the gastrointestinal tract, primarily bound to the erythrocytes $\left(\mathrm{t}_{1 / 2} 1-2\right.$ months) and accumulated in the kidney again as nuclear inclusion bodies $\left(\mathrm{t}_{1 / 2} \sim 7\right.$ years) and in the bones $\left(\mathrm{t}_{1 / 2} \sim 32\right.$ years). The latter amounts to $95 \%$ of the total body lead and is incorporated as $\mathrm{Pb}_{3}\left(\mathrm{PO}_{4}\right)_{2}$ due to its similarity to $\mathrm{Ca}^{2+}$. As such, this insoluble lead mineral is not harmful (denoted as Depotblei in German), but becomes a problem when the body starts tapping its bone calcium 'storage' trying to counteract a calcium deficiency. Lead most often causes chronic poisoning. Organic lead compounds (like organic mercury and tin) easily pass membranes such as the blood-brain barrier and lead generally to myelin sheath damage (the lipid membrane that protects the nerve axons) impairing signal transduction. Lead is also teratogenic and causes anaemia by inhibition of the heme-biosynthesis. The major cause is the inhibition of the $\mathrm{Zn}^{2+}$-enzyme $\delta$-aminolevulinic acid dehydratase ( $\delta$-ALA-dehydratase) by $\mathrm{Pb}^{2+}$. The mechanism of inhibition is specific for enzymatic inhibition by lead and is determined by the differences in coordination geometry between $\mathrm{Zn}^{2+}$ and $\mathrm{Pb}^{2+}$ : while all $\mathrm{Pb}^{4+}$ complexes show holodirected coordination geometry, the coordination geometry of $\mathrm{Pb}^{2+}$ and hence the nature of the lead lone pair depends on the ligands. High coordination numbers and soft bulky ligands with strong interligand repulsion lead to a lone pair with more s-character and hence holodirected coordination geometry. In contrast, low coordination numbers and hard ligands with attractive interactions between the ligands result in a lone pair with more p-character leading to hemidirected coordination geometries. ${ }^{[51]}$ That the latter coordination mode is prevalent in $\delta$-ALA-dehydratase was shown with calculations and a crystallographic study of a model compound. ${ }^{[52]}$ Certainly, with a lone pair with p-character occupying the fourth free coordination site required for substrate binding in the $\mathrm{Zn}^{2+}$-enzyme, all enzymatic activity will be completely blocked (and not just reduced as sometimes observed in enzymes inhibited by $\mathrm{Cd}^{2+}$ ).

Lastly, we want to mention arsenic as one of the probably least understood toxic heavy metals. It is found in lead- and copper alloys, as anti-weed and pest treatment (in part forbidden), as pigment (auripigment $\left(\mathrm{As}_{2} \mathrm{~S}_{3}\right)$, realgar $\left(\mathrm{As}_{4} \mathrm{~S}_{4}\right)$ ), and formerly also as the first organometallic medical drug (salvarsan) against syphilis. ${ }^{[45]}$ While arsenic is regarded as potent poison and carcinogen, its essentiality is also debated in low concentrations of approximately 5-50 $\mu \mathrm{g} /$ day (actual intake $\sim 1 \mathrm{mg} /$ day!). Arsenic stimulates formation of red blood cells and was used for horse doping and by mountain farmers and lumbermen in Tirol and the Steiermark (arsenic eaters) using a dose of up to $250 \mathrm{mg}$ twice per week (a deadly dose for a normal person). Hence, apparently, a gradual increase of tolerance against arsenic can be achieved (mechanism unknown) and has been used historically by high-ranking persons as 'protection' against murder with poison. Anecdotally, Mithridates VI. (132 BC) developed such a large tolerance that his own attempt to commit suicide with $\mathrm{As}_{2} \mathrm{O}_{3}$ failed after his defeat to Pompeius - and he had to ask to be stabbed 
instead. If not deadly, arsenic can cause enzyme inhibition owing to its thiophilicity, including inhibition of $\delta$-ALA-dehydratase as with $\mathrm{Pb}^{2+}$ and can be incorporated into ATP due to the similarity of arsenate with phosphate.

\section{Conclusions}

The Bioinorganic Periodic Table of the Elements is obviously key to Life and Death of all living organisms. Here, we could only show a small glimpse of the manifold aspects of these elements that make up a major part of the Periodic Table. Crucial for innumerable chemical reactions in the cell, structural stability of biomacromolecules, tissues and bone, tightly regulated, and sometimes stored for bad times, we realise that we have only started to scratch at the surface of understanding the highly complex network and interplay of metals in living organisms. With this short overview, which is neither comprehensive nor detailed in any aspect, we hope to have triggered the interest of the reader to dig further into the Bioinorganic Periodic Table of the Elements.

\section{Acknowledgements}

We thank all our past and present group members for their hard work, enthusiasm, and great atmosphere in the lab. Continuous financial support from the Swiss National Science Foundation (EF and RKOS) and the University of Zurich, but also from many other sources, including the UZH Forschungskredit (EF and RKOS), the Swiss State Secretariat for Education, Research and Innovation (COST Actions D39 and CM1105, to EF and RKOS), and the ERC (RKOS) is gratefully acknowledged.

Received: February 15, 2019

[1] A. F. Holleman, E. Wiberg, N. Wiberg, 'Lehrbuch der Anorganischen Chemie', 102. Auflage, de Gruyter, Berlin 2007.

[2] 'Biogeochemical Cycles of Elements', Eds. A. Sigel, H. Sigel, R. K. O. Sigel, Taylor \& Francis Group, Boca Raton FL, USA, 2005, Met. Ions Biol. Syst. 43, $301 \mathrm{pp}$.

[3] 'Biogeochemistry, Availability, and Transport of Metals in the Environment', Eds A. Sigel, H. Sigel, R. K. O. Sigel, Taylor \& Francis Group, Boca Raton, FL, USA, 2005, Met. Ions Biol. Syst., 44, 298 pp.

[4] B. J. Alloway, 'Zinc in Soils and Crop Nutrition', $2^{\text {nd }}$ edn., published by the International Zinc Association (IZA) and the International Fertilizer Industry Association (IFA), Brussels, Belgium and Paris, France, 2008

[5] 'Handbook of Chemistry and Physics', $71^{\text {st }}$ edn., CRC Press.

[6] M. C. Erat, R. K. O. Sigel, Met. Ions Life Sci. 2011, 9, 37.

[7] 'The Natural Selection of the Chemical Elements', Eds. R. J. P. Williams, J. J. R. Fraústo da Silva, Clarendon Press, Oxford, 1996, pp. 646.

[8] M. Olivares, R. Uauy, 'Essential Nutrients in Drinking Water', WHO Report, 2004

[9] C. Murphy, C. Schaffrath, D. O'Hagan, Chemosphere 2003, 52, 455.

[10] A. Scott McCall, C. F. Cummings, G. Bhave, R. Vanacore, A. Page-McCaw, B. G. Hudson, Cell 2014, 157, 1380.

[11] J. B. Vincent 'Chromium: Biological Relevance', in 'Encyclopedia of Inorganic Chemistry', John Wiley, New York, 2005

[12] M. Pechlaner, R. K. O. Sigel, Met. Ions Life Sci. 2012, 10, 1.

[13] 'Principles of Bioinorganic Chemistry', Eds. S. J. Lippard, J. M. Berg, University Science Books, Mill Valley, California, 1995.

[14] 'The Biological Chemistry of Magnesium', Ed. J. A. Cowan, VCH Publishers, Inc., New York, 1995.
[15] T. Pan, D. M. Long and O. C. Uhlenbeck, in 'The RNA World', Eds. R. Gesteland, J. Atkins, Cold Spring Harbor Press, Cold Spring Harbor, 1993 pp. 271-302.

[16] L. A. Finney, T. V. O’Halloran, Science 2003, 300, 931

[17] 'The Alkali Metal Ions: Their Role for Life', Eds. A. Sigel, H. Sigel, R. K. O. Sigel, Springer, Dordrecht, NL, 2016, Met. Ions Life Sci., 16, 628 pp.

[18] 'The RNA World', Eds. R. F. Gesteland, T. R. Cech, J. F. Atkins, $3^{\text {rd }}$ edn., Cold Spring Harbor Laboratory Press 2005, 768 pp.

[19] 'Structural and Catalytic Roles of Metal Ions in RNA', Eds A. Sigel, H. Sigel, R. K. O. Sigel, Royal Society of Chemistry, Cambridge, UK, 2011 , Met. Ions Life Sci., 9, 423 pp.

[20] R. K. O. Sigel, H. Sigel, Compr. Inorg. Chem. II 2013, 3, 623.

[21] H. Guiset Miserachs, D. Donghi, R. Börner, S. Johannsen, R. K. O. Sigel, J. Biol. Inorg. Chem. 2016, 21, 975.

[22] 'Bioinorganic Chemistry - Inorganic Elements in the Chemistry of Life', Eds. W. Kaim, B. Schwederski, A. Klein, Wiley, $2^{\text {nd }}$ edn, 2013.

[23] 'Handbook of Metalloproteins', Eds. I. Bertini, A. Sigel, H. Sigel, 2001, Marcel Dekker, New York; 'Handbook of Metalloproteins', Ed. A Messerschmidt, 2007, Wiley-Blackwell.

[24] Series 'Metal Ions in Life Sciences', Eds. E. Freisinger (since vol 18), A Sigel, H. Sigel, R. K. O. Sigel, Walter DeGruyter, Berlin.

[25] J. Stubbe, Curr. Opin. Chem. Biol. 2003, 7, 183.

[26] A. Jordn, P. Reichard, Annu. Rev. Biochem. 1998, 67, 71.

[27] H. Sigel, Coord. Chem. Rev. 1990, 100, 453.

[28] H. Sigel, Inorg. Chim. Acta 1992, 198-200, 1.

[29] H. Sigel, F. Hofstetter, R. B. Martin, R. M. Milburn, V. Scheller-Krattiger, K. H. Scheller, J. Am. Chem. Soc. 1984, 106, 7935.

[30] T. A. Steitz, J. A. Steitz, Proc. Natl. Acad. Sci. USA 1993, 90, 6498

[31] G. Schenk, N. Mitic, G. R. Hanson. P. Comba, Coord. Chem. Rev. 2013, 257, 473.

[32] 'Metallomics and the Cell', Ed. L. Banci, series Eds. A. Sigel, H. Sigel, R. K. O. Sigel, Springer, Dordrecht, NL, 2013 Met. Ions Life Sci., 12, 608 pp.

[33] W. J. G. M. Peijnenburg, R. Baerselman, A. C. de Groot, T. Jager, L. Posthuma, R. P. M. Van Veen, Ecotox. Environ. Safe. 1999, 44, 294.

[34] T. Kambe, A. Hashimoto, S. Fujimoto, Cell. Mol. Life Sci. 2014, 71, 3281.

[35] A. Bhattacharjee, K. Chakraborty, A. Shukla, Metallomics 2017, 9, 1376.

[36] C. Cheng, S. Juul, NeoReviews 2011, 12, e148.

[37] T. E. Adams, A. B. Mason, Q.-Y. He, P. J. Halbrooks, S. K. Briggs, V. C. Smith, R. T. A. MacGillivray, S. J. Everse, J. Mol. Biol. 2003, 27, 6027.

[38] B. S. Stein, H. H. Sussman, J. Biol. Chem. 1983, 258, 2668.

[39] S. T. Sawyer, S. B. Krantz, J. Biol. Chem. 1986, 261, 9187.

[40] A. Dautry-Varsat, A. Ciechanover, H. F. Lodish, Proc. Natl. Acad. Sci. USA 1983, 80,2258

[41] M.-T. Nunez, V. Gaete, J. A. Watkins, J. Glass, J. Biol. Chem. 1990, 265 , 6688.

[42] R. L. Huff, T. G. Hennessey, R. E. Austin, J. F. Garcia, B. M. Roberts, J. H Lawrence, J. Clin. Invest. 1950, 29, 1041.

[43] P. M. Harrison, P. Arosio, Biochim. Biophys. Acta 1996, 1275, 161.

[44] C. P. Anderson, M. Shen, R. S. Eisenstein, E. A. Leibold, Biochem. Biophys. Acta 2012, 1823, 1468.

[45] R. Braun, G. F. Fuhrmann, W. Legrum, C. Steffen, 'Spezielle Toxikologie für Chemiker', Springer-Verlag, 2013.

[46] 'Cadmium: From Toxicity to Essentiality', Eds A. Sigel, H. Sigel, R. K. O. Sigel, Springer, Dordrecht, NL, 2013, Met. Ions Life Sci., 11, 560 pp.

[47] S. Rufer, 'Teure Edel-Schokolade ist nur «genügend»', K-Tipp 2007, 15, 8-9.

[48] M. Margoshes, B. L. Vallee, J. Am. Chem. Soc. 1957, 79, 4813.

[49] V. Alterio, E. Langella, G. De Simone, S. M. Monti, Marine Drugs 2015, 13 , 1688.

[50] 'Lead: Its Effects on Environment and Health', Eds A. Sigel, H. Sigel, R. K. O. Sigel, Walter de Gruyter GmbH, Berlin, DE, 2017, Met. Ions Life Sci., 17, 596 pp.

[51] L. Shimoni-Livny, J. P. Glusker, C. W. Bock, Inorg. Chem. 1998, 37, 1853.

[52] C. Gourlaouen, O. Parisel, Angew. Chem. Int. Ed. 2007, 119, 559. 